\title{
Nutrient and Sediment Transport on Flood-Irrigated Pasture in the Klamath Basin, Oregon
}

\author{
D. Ciotti, ${ }^{1}$ S. M. Griffith, ${ }^{2}$ J. Kann, ${ }^{3}$ and J. Baham ${ }^{4}$ \\ Authors are ${ }^{1}$ Biologist, Klamath Falls Fish and Wildlife Office, US Fish and Wildlife Service, Klamath Falls, OR 97601, USA; ${ }^{2}$ Research Plant \\ Physiologist, National Forage Seed Production Research Center, US Department of Agriculture-Agricultural Research Service, Corvallis, OR 97331, USA; \\ ${ }^{3}$ Aquatic Ecologist, Aquatic Ecosystem Sciences LLC, Ashland, OR 97520, USA; and ${ }^{4}$ Associate Professor, Department of Crop and Soil Science, Oregon \\ State University, Corvallis, OR 97331, USA.
}

\begin{abstract}
Distinguishing between anthropogenic and natural sources of sediment and nutrients is important for water resource management in irrigated basins. Water quality of flood irrigation was monitored at the field scale in the upper Klamath Basin, Oregon, on two unfertilized cattle pastures that were 2 ha (Site 1) and 70 ha (Site 2) in area. Water samples were analyzed for concentrations of sediment, total dissolved nitrogen (TDN), total dissolved phosphorus (TDP), orthophosphate, ammonium-N $\left(\mathrm{NH}_{4}^{+}-\mathrm{N}\right)$, and nitrate- $\mathrm{N}\left(\mathrm{NO}_{3}^{-}-\mathrm{N}\right)$. At both sites the TDN concentration was significantly greater in surface runoff than in applied irrigation water $(P<0.05)$. Site 1 sediment and TDP concentrations were significantly greater in irrigation surface runoff than in applied irrigation water $(P<0.05)$. A first flush during irrigation was observed at Site 1 where nutrient concentration was at maximum value during the first $3 \mathrm{~h}$ of surface runoff. At Site 2 the surface runoff sediment and TDP concentrations were not significantly $(P>0.05)$ higher than the applied irrigation, except when cattle were present. When export was measured, the mean yield of sediment and TDN per irrigation was $23.9 \mathrm{~kg} \mathrm{~N} \cdot \mathrm{ha}^{-1}$ and $0.26 \mathrm{~kg} \mathrm{~N} \cdot \mathrm{ha}^{-1}$, respectively, and there was a net retention of TDP of $0.04 \mathrm{~kg} \mathrm{P} \cdot \mathrm{ha}^{-1} \cdot \mathrm{NH}_{4}^{+}-\mathrm{N}$ export occurred during one irrigation event yielding $0.15 \mathrm{~kg} \mathrm{~N} \cdot \mathrm{ha}^{-1}$. $\mathrm{NO}_{3}^{-}-\mathrm{N}$ export was minimal or undetected. A late summer storm event resulted in pasture surface runoff concentrations of TDN and TDP that were 33 and 3 times higher, respectively, than irrigation source water concentrations. The TDN was significantly higher in subsurface runoff than it was in applied irrigation water $(P<0.05)$. Improved irrigation efficiency might prevent many of the nutrient and sediment transport mechanisms observed during this study.
\end{abstract}

\section{Resumen}

La habilidad de distinguir entre fuentes de nutrientes y sedimentos antropogénicos y naturales es importante para el manejo de recursos hídricos de cuencas irrigadas. Se monitoreó la calidad del agua de riego por inundación medida a escala de potrero en la cuenca superior del rio Klamath en Oregon, EE.UU., en dos pasturas sin fertilizar pastoreadas por bovinos, una de 2 (Sitio 1) y otra de 70 ha (Sitio 2) de superficie. Se analizaron muestras de agua para determinar contenido de sedimentos, nitrógeno disuelto total (NDT), fósforo disuelto total (PDT), ortofosfato (OP), nitrógeno en amonio $\left(\mathrm{NH}_{4}^{+}-\mathrm{N}\right)$, y nitrógeno en nitratos $\left(\mathrm{NO}_{3}^{-}-\mathrm{N}\right)$. En ambos sitios la concentración de NDT fue significativamente más alta en aguas de escorrentía superficial que en el agua de riego aplicada $(P<0.05)$. En el Sitio 1 , la concentración de sedimentos y NDT fue significativamente más alta en escorrentía superficial de agua de irrigación que en el agua de riego $(P<0.05)$. Se observó un pulso inicial durante las primeras $3 \mathrm{~h}$ de escurrimiento superficial durante el riego en el Sitio 1 en el que la concentración de nutrientes alcanzó valores máximos. En el Sitio 2 la concentración de sedimentos y PDT en aguas de escurrimiento superficial no fue significativamente $(P<0.05)$ más alta que en el agua de riego aplicada, excepto en presencia de bovinos. La concentración de sedimentos y NDT exportados por evento de riego fue 23,9 y $0,26 \mathrm{~kg} \mathrm{~N} \cdot \mathrm{ha}^{-1}$, respectivamente, y hubo una retención neta de PDT de $0,04 \mathrm{~kg} \mathrm{P} \cdot \mathrm{ha}^{-1}$. Se detectó $\mathrm{N}$ exportado en forma de amonio durante un evento de riego a razón de $0,15 \mathrm{~kg} \mathrm{~N} \cdot \mathrm{ha}^{-1}$. El $\mathrm{N}$ exportado en forma de nitratos fue mínimo o no pudo ser detectado. Una tormenta tardía de verano resultó en concentraciones de NDT y PDT en aguas de escurrimiento superficial que fueron 33 y 3 veces superiores, respectivamente, a las concentraciones en aguas de irrigación. El NDT fue significativamente más alto en aguas de escurrimiento sub-superficial que en el agua de riego aplicada $(P<0.05)$. Una mejora en la eficiencia de riego podría prevenir muchos de los mecanismos de transporte de sedimentos y nutrientes observados durante este estudio.

Key Words: grass, grazing, irrigation, nitrogen, pasture, water quality

The use of trade, firm, or corporation names in this publication is for the information and convenience of the reader. Such use does not constitute an official endorsement or approval by the US

Department of Agriculture or the Agricultural Research Service of any product or service to the exclusion of others that may be suitable.

At the time of the research, Ciotti was a research assistant in Environmental Sciences, Oregon State University, Corvallis, OR 97331, USA.

Correspondence: S. M. Griffith, National Forage Seed Production Research Center USDA-ARS, 3450 SW Campus Way, Corvallis, OR 97331, USA. Email: Steve.Griffith@ars.usda.gov

Manuscript received 14 May 2008; manuscript accepted 19 December 2009. 


\section{INTRODUCTION}

About $22 \%$ of the nonfederal land in the United States is rangeland (US Department of Agriculture Natural Resources Conservation Service [USDA NRCS]). Transport of nutrients and sediment from range and pasturelands is an environmental concern, particularly in the arid West where large portions of watersheds are utilized for cattle grazing, and especially when irrigation is involved. Transport of surface water pollutants may be accelerated where pastures are flood-irrigated. Protection of and improvements to water quality requires identification of source areas and transport mechanisms of pollutants and distinguishing between natural and anthropogenic sources.

Pasture management practices including irrigation flow rates, fertilizer application, and animal stocking density influence the mobilization and transport of pollutants from flood-irrigated pasture (Schepers and Francis 1982; Bush and Austin 2001; Cessna et al. 2001; Mundy et al. 2003). Sediment transport may result from disturbances caused by cattle. Owens et al. (1989) compared sediment concentrations from a catchment for $2 \mathrm{yr}$ without livestock $\left(0.8 \mathrm{~g} \cdot \mathrm{L}^{-1}\right), 3 \mathrm{yr}$ with summer grazing only $\left(1.3 \mathrm{~g} \cdot \mathrm{L}^{-1}\right)$, and an additional $6 \mathrm{yr}$ grazing all year round $\left(3.2 \mathrm{~g} \cdot \mathrm{L}^{-1}\right)$. Surface runoff from fertilized and irrigated dairy pastures contributes significant phosphorus $(\mathrm{P})$ loads to waterways (Bush and Austin 2001). Cessna et al. (2001) found concentrations of $\mathrm{P}$ in canals draining flood-irrigated and fertilized cropland to vary from $0.02 \mathrm{mg} \mathrm{P} \cdot \mathrm{L}^{-1}$ to $>1.5 \mathrm{mg} \mathrm{P} \cdot \mathrm{L}^{-1}$ but ammonium- $\mathrm{N}\left(\mathrm{NH}_{4}^{+}-\mathrm{N}\right)$ and nitrate- $\mathrm{N}\left(\mathrm{NO}_{3}^{-}-\mathrm{N}\right)$ concentrations were low. Spreading of cattle dung pats on pasture surface caused higher total $\mathrm{P}(\mathrm{TP})$ in irrigation surface runoff during the first irrigation event of the year and the load of nitrogen $(\mathrm{N})$ in pasture surface runoff was more dependent on cattle density (Mundy et al. 2003). Few studies closely examined the water quality impacts of flood irrigation on unfertilized cattle pastures.

Approximately $14 \%$ of agricultural land in the Upper Klamath Lake watershed in southern Oregon is flood-irrigated cattle pasture (USDA NRCS 2005). Pastures are flooded about every $7 \mathrm{~d}$ to $14 \mathrm{~d}$ from April until October. Water draining from many of the pastures is returned to tributaries of Upper Klamath Lake. The Upper Klamath Lake subbasin was listed on the 1998 Oregon 303(d)1 list for dissolved oxygen, chlorophyll a, and pH (Oregon Department of Environmental Quality 2002). Irrigation surface runoff and drainage is identified as a nutrient source to Upper Klamath Lake (Rykbost and Charlton 2001). Upper Klamath Lake is considered naturally eutrophic with certain tributaries having relatively high background levels of $\mathrm{P}$ and sediment. The State of Oregon proposes to reduce phosphorus loads to Upper Klamath Lake by $40 \%$. Alternative watershed and land use management strategies could reduce nutrient and sediment transport to Upper Klamath Lake (Gearheart et al. 1995; Anderson 1998). Achieving designated beneficial uses for waterways requires determining the cause of impairment (Nelson et al. 1996; Lewis et al. 2006). An understanding of mobilization and transport of sediment and nutrients on pastures at the plot scale can indicate relative contributions from both background sources and from specific cattle and irrigation management practices, as well as assist in identifying potential management alternatives.

The objective of this research was to examine the spatial (above-, within-, and below-pasture) and temporal (seasonal) patterns of water transport of sediment and nutrients on irrigated cattle pastures in the Upper Klamath Lake basin. Pastures play a critical role in ranch enterprises and can make rangeland-based ranching profitable and add overall grazing flexibility. Here we report a surface water, sediment, and nutrient budget for two flood irrigation events on grazed cattle pasture. Comparisons of nutrient and sediment concentrations and physical water quality parameters were also made between irrigation inflow, surface runoff, shallow groundwater, and storm surface runoff from flood-irrigated pastures during 12 irrigations for two seasons, 2003 and 2004. The irrigation source water in this study was mostly unaffected by anthropogenic inputs prior to being used for flood irrigation. This research provides a focused look at how cattle and irrigation management practices impact sediment and nutrient transport on small, unfertilized pasture plots $(<100 \mathrm{ha})$.

\section{MATERIALS AND METHODS}

\section{Site Description}

The study sites were located in the Wood River Valley portion of the Upper Klamath Lake watershed in Klamath County, south-central Oregon. Elevation is $1300 \mathrm{~m}$ with slopes ranging from $0 \%$ to $3 \%$. The Wood River Valley is surrounded by steep mountain ridges of the Cascades to the north, east, and west, and by Agency and Upper Klamath lakes to the south. The climate is semiarid, with most precipitation occurring during the cold winter months. Average annual precipitation varies from $406 \mathrm{~mm}$ to $607 \mathrm{~mm}$ and average annual air temperature ranges from $5.5^{\circ} \mathrm{C}$ to $6.7^{\circ} \mathrm{C}$ (USDA NRCS 1985). The Cascade Mountains feed the Wood River Valley with snowmelt and numerous spring-fed creeks.

Waterways throughout the valley are utilized for gravity-fed flood irrigation of cattle pasture. Cattle are usually brought into the valley by truck in April and grazed through October. The pastures are irrigated about every 2 wk from April through September. Pastures are typically not chemically fertilized. Primary sources of irrigation water include streams and springs flowing out of the Cascade Mountains. Most of the irrigation tailwater (surface runoff) flows to canals before emptying into Upper Klamath Lake. Dominant pasture grasses include Kentucky bluegrass (Poa pratensis L.), timothy (Phelum pretense L.), Baltic rush (Juncus balticus Willd.), Nebraska sedge (Carex nebraskensis Dewey), and a variety of Agrostis sp. Woody species dominate riparian areas and the perimeter of the valley. The soils are volcanic in origin and poorly drained with a loamy A horizon over a sandy and gravelly loam B horizon. The soils are classified as Ashy-pumaceous, glassy, nonacid Typic Cryaquands (USDA NRCS 1985).

Site 1. In 2003, a 2-ha pasture study site located at approximately lat $42^{\circ} 71^{\prime} 18^{\prime \prime} \mathrm{N}$, long $122^{\circ} 06^{\prime} 76^{\prime \prime} \mathrm{W}$ was sampled. The area of the site was estimated from the surface wetted perimeter during flood irrigation. The site was part of a fenced pasture totaling 28 ha irrigated and stocked at 0.5 cattle $\cdot \mathrm{ha}^{-1}$, which is moderate for the Wood River Valley. The irrigation source was Sevenmile Creek, which flows out of the Winema National Forest. The irrigation inflow water had limited agricultural influence because it flowed primarily through 
national forest land. Water samples were collected from Sevenmile Creek in the national forest and from the irrigation inflow diversion. The irrigation applications were controlled manually by a canal headgate. Flow was measured at inflow and surface runoff locations. The inflow volume was measured with a flow meter $(122 \mathrm{~cm}$ top-set wading rod, JBS Instruments AquaCalc 5000-Advanced Stream Flow Computer and Pygmy meter). Irrigation surface runoff from the pasture was measured with two rectangular sharp-crested weirs at two swales at the bottom of the field where surface runoff concentrated (US Department of the Interior Bureau of Reclamation 1997). Surface runoff typically increased during the first 24-h period of irrigation inflow and then stabilized for the remaining hours. Water quality samples were taken during five irrigations from June 2003 through August 2003 and during one storm in September 2003.

Flood irrigations lasted for about $24-48$ h. Irrigation inflow was sampled from canals at the point of irrigation diversion onto the field and surface runoff grab samples were collected directly from the pasture field surface before water flowed into irrigation tailwater ditches. About six pasture surface runoff samples were collected as surface runoff flow increased during the first $12 \mathrm{~h}$ of each irrigation, and two to three samples were collected after pasture surface runoff flow reached equilibrium. A nutrient budget was estimated for Site 1 during the third and fourth irrigations. Shallow groundwater quality samples were also collected at a depth of 1-2 m.

Site 2. In 2004 the study was moved to a 70-ha fenced and irrigated cattle pasture (lat $42^{\circ} 73^{\prime} 22^{\prime \prime} \mathrm{N}$, long $122^{\circ} 01^{\prime} 02^{\prime \prime} \mathrm{W}$ ) about $5 \mathrm{~km}$ northeast of study Site 1 . It was stocked with 1.6 cattle $\cdot \mathrm{ha}^{-1}$. The site was irrigated by water from Annie Creek, which flows out of Crater Lake National Park. This irrigation source water had little to no exposure to other irrigation surface runoff or cattle disturbance. All flows were measured with a flow meter. The 70-ha site was sampled from May 2004 through August 2004 during seven irrigations. Water samples were collected from inflow and surface runoff canals, from shallow groundwater, and from Annie Creek in the national park. Determining a water, sediment, and nutrient budget at Site 2 presented difficulties because of the mixing of irrigation inflow with surface runoff in ditches and the inability to measure all surface runoff. Only instantaneous loads were computed.

\section{Sample Collection and Analysis}

Surface water samples were collected as grab samples in 250$\mathrm{mL}$ polyethylene bottles. Shallow groundwater samples were collected from polyvinyl chloride piezometer wells $(5-\mathrm{cm}$ diameter) along transects at both the 2-ha and 70-ha sites. Wells were installed to a depth of 1-1.8 m. Bentonite clay was packed around the well from the surface down to $25 \mathrm{~cm}$. Groundwater samples were collected with a polyethylene tube and $250-\mathrm{mL}$ syringe. Wells were pumped empty and allowed to refill to ensure that water samples represented actual soil water characteristics.

Water quality samples were filtered with $0.45-\mu \mathrm{m}$ filters prior to chemical analysis. The filters were preweighed and oven-dried at $105^{\circ} \mathrm{C}$ and sediment concentration was determined. $\mathrm{NH}_{4}^{+}-\mathrm{N}$ and $\mathrm{NO}_{3}^{-}-\mathrm{N}$ concentrations were determined by flow injection colorimetry with a Lachat QuikChem 4200 analyzer. Total dissolved $\mathrm{N}$ concentration (TDN) was determined by chemiluminescence with a Shimadzu total nitrogen (TN) analyzer. Total organic carbon (TOC) concentration was determined using a high-temperature catalytic combustion Shimadzu TOC-V analyzer. Orthophosphate (ortho-P) was determined with flow injection analysis, colorimetric Lachat QuikChem method 10115-01-1-B. Total dissolved P (TDP) was determined with flow injection analysis colorimetry (potassium persulfate digestion) Lachat QuikChem method 10-115-01-4-S.

\section{Data Analysis}

All statistics were performed using Minitab version 14 software. Multiple comparisons were made to determine significant differences between mean nutrient and sediment concentration for all sites using analysis of variance (ANOVA). Instantaneous sediment and nutrient loading rates were calculated for surface water samples by multiplying concentrations with flow volume at the time of sampling:

$$
\mathrm{M}=\mathrm{CV}
$$

where $\mathrm{M}$ is total mass in a volume $\mathrm{V}$ of water and $\mathrm{C}$ is the constituent concentration (Maidment 1993). Because nutrient and sediment concentration and irrigation flow were not measured continuously throughout the irrigation for the Site 1 budget, linear interpolation was used to estimate changes in load among known loading rates.

Export from surface waters during two irrigation events in 2003 was determined by the difference between the total mass of sediment and nutrients in the irrigation water inflow and surface runoff. Because a nutrient or sediment budget could not be estimated in 2004 we compared flow-weighted concentrations (FWC) for irrigation inflow and surface runoff canals. FWC is an overall measure of water quality for a particular sampling site and the weight assigned to a nutrient concentration is relative to the flow (Sether et al. 2004). FWC was computed for sampling sites by dividing the total of the constituent load measured at a sample site by the total of flow volumes measured at the sample site. Shallow groundwater concentration of nutrients was compared with surface water but the subsurface nutrient load was not estimated.

\section{RESULTS}

\section{Air Temperature and Precipitation}

The mean air temperature for May through September during 2003 and 2004 was $15^{\circ} \mathrm{C}$ and $14^{\circ} \mathrm{C}$, respectively. Total precipitation for May 2003 through September 2003 was $3.6 \mathrm{~cm}$; it was $5.2 \mathrm{~cm}$ in 2004. Most precipitation events were less than $0.5 \mathrm{~cm} \cdot \mathrm{d}^{-1}$. On 9 September 2003, $2.6 \mathrm{~cm}$ of precipitation fell within a 24 -h period. This was the only storm that produced surface runoff at the sampling sites during the 2003 and 2004 irrigation seasons.

\section{Irrigation Water Quality}

A two-sample $t$ test was used to compare water quality parameters between inflow and outflow for surface waters of 
Table 1. Summary of mean \pm SEM for turbidity, $\mathrm{pH}$, and specific conductivity of water at irrigation inflow (point of diversion onto pasture) and outflow (surface runoff) from two study sites. Asterisks $\left(^{*}\right)$ indicate a significant difference between irrigation inflow and outflow for the respective site at $P<0.05$ (two-sample $t$ test). ${ }^{1}$

\begin{tabular}{cccccc}
\hline Site & Treatment & Samples & Turbidity (NTU) & pH & Specific conductance (mS) \\
\hline 1 & Inflow & 15 & $2.98 \pm 1.3$ & $7.34 \pm 0.03^{*}$ & $0.055 \pm 0.003$ \\
& Outflow & 51 & $6.59 \pm 1.2$ & $7.10 \pm 0.03$ & $0.056 \pm 0.002$ \\
2 & Inflow & 25 & $4.96 \pm 0.3$ & $7.63 \pm 0.13^{*}$ & $0.049 \pm 0.001^{\star}$ \\
& Outflow & 59 & $5.42 \pm 0.3$ & $7.38 \pm 0.05$ & $0.067 \pm 0.002$ \\
\hline
\end{tabular}

${ }^{1} \mathrm{NTU}$ indicates Nephelometric Turbidity Unit; mS, milli Semen.

both study sites (Table 1). In comparing inflow and outflow chemistry, it was found for both sites that $\mathrm{pH}$ was significantly higher in the inflow water compared to the outflow and specific conductance higher only in the inflow at Site 2. Turbidity remained unchanged for inflow and outflow at both sites. Nutrient and sediment concentrations were compared for irrigation source water and inflow and irrigation surface runoff for both study sites (Table 2). The irrigation inflow nutrient concentrations at both sites were similar to their respective irrigation source water nutrient concentrations. Nutrient concentrations were generally higher in the irrigation surface runoff, shallow groundwater, and storm surface runoff than in the inflow or irrigation source water sites and significant differences are presented (Fig. 1).

The highest concentrations of nutrients measured at Site 1 occurred early in the irrigation surface runoff period (Figs. 2 and 3). Nutrient concentrations were also higher in surface runoff during irrigations earlier in the season. It was found that TOC was not significantly $(P>0.05)$ different in surface or shallow ground water at either site. Mean surface runoff TDN and TDP concentrations were $31 \%$ and $51 \%$ higher, respectively, during the first three irrigations than they were during the fourth and fifth irrigations at Site 1. TDP in the inflow water was generally low during all irrigations. $\mathrm{NH}_{4}^{+}-\mathrm{N}$ concentration in the surface runoff was higher than the inflow but did not follow a strong temporal pattern. Holstein dairy cows were stocked on Site 1 at a rate of 0.5 cows $\cdot \mathrm{ha}^{-1}$; the cows roamed across the plot during and after irrigation. The extent of livestock presence was noted during sampling and was not associated with increased sediment or nutrients in irrigation surface runoff. The high nutrient concentrations at Site 1 occurred primarily in the surface runoff water during the rising limb of the surface runoff hydrograph. Site 1 had few bare soil spots and dense pasture growth on the field, which likely limited the soil disturbance caused by cattle or storm surface runoff.

Site 2 soil N content was $90 \%$ higher than that of Site 1 . Site 2 also had a cattle stocking density three times higher. TDN concentrations were significantly higher in the irrigation surface runoff and shallow groundwater than they were in the applied irrigation water at Site $2(P<0.05$; ANOVA). The highest $\mathrm{NH}_{4}^{+}-\mathrm{N}$ and $\mathrm{NO}_{3}^{-}-\mathrm{N}$ concentrations $\left(1.01 \mathrm{mg} \mathrm{N} \cdot \mathrm{L}^{-1}\right.$ and $0.47 \mathrm{mg} \mathrm{N} \cdot \mathrm{L}^{-1}$, respectively) occurred in surface runoff from Site 2. The raw mean $\mathrm{NH}_{4}^{+}-\mathrm{N}$ concentration in irrigation surface runoff was 2.6 times higher than irrigation source water at Site 1 and 7.7 times higher than irrigation source water at Site 2.

Mean TDP concentration in irrigation surface runoff at Site 1 was $0.15 \mathrm{mg} \mathrm{P} \cdot \mathrm{L}^{-1}$ and was significantly higher than the applied irrigation TDP $\left(0.08 \mathrm{mg} \mathrm{P} \cdot \mathrm{L}^{-1} ; P<0.05\right.$; ANOVA $)$. Site 1 had a TDP concentration of $0.05 \mathrm{mg} \mathrm{P} \cdot \mathrm{L}^{-1}$ in the irrigation source water from Sevenmile Creek. At Site 2 the mean TDP concentration was $0.09 \mathrm{mg} \mathrm{P} \cdot \mathrm{L}^{-1}$ and there was no significant difference between TDP concentration of irrigation runoff and the applied irrigation water. Overall mean TDP concentration in shallow groundwater was $0.06 \mathrm{mg} \mathrm{P} \cdot \mathrm{L}^{-1}$.

Table 2. Summary of mean \pm SEM concentrations of sediment, TOC, ${ }^{1} \mathrm{TDP}$, ortho-P, $\mathrm{TDN}, \mathrm{NH}_{4}^{+}-\mathrm{N}$, and $\mathrm{NO}_{3}^{-}-\mathrm{N}$ at source headwater creeks, inflow (point of diversion onto pasture), outflow (surface runoff), storm runoff (surface water), and groundwater (at about 1-m depth) from two study sites. Asterisks $\left({ }^{\star}\right)$ indicate a significant difference between headwater stream values and other locations at respective study sites at $P<0.05$ (ANOVA).

\begin{tabular}{|c|c|c|c|c|c|c|c|c|c|}
\hline Site & Treatment & Samples & Sediment & TOC & TDN & TDP & $\mathrm{NH}_{4}^{+}-\mathrm{N}$ & $\mathrm{NO}_{3}^{-}-\mathrm{N}$ & Ortho-P \\
\hline & & & & & & $-m g \cdot L$ & & & \\
\hline \multirow[t]{5}{*}{1} & Sevenmile Creek & 18 & $1.39 \pm 0.23$ & - & $0.06 \pm 0.005$ & $0.06 \pm 0.003$ & $0.01 \pm 0.002$ & $0.01 \pm 0.001$ & $0.06 \pm 0.003$ \\
\hline & Inflow & 16 & $13.69 \pm 3.47$ & $10.06 \pm 0.878$ & $0.12 \pm 0.029$ & $0.08 \pm 0.006$ & $0.03 \pm 0.002$ & $0.03^{\star} \pm 0.000$ & $0.07 \pm 0.003$ \\
\hline & Outflow & 58 & $16.54^{*} \pm 2.14$ & $18.29 \pm 1.10$ & $0.44^{\star} \pm 0.042$ & $0.15^{\star} \pm 0.017$ & $0.04 \pm 0.003$ & $0.03^{\star} \pm 0.000$ & $0.13^{*} \pm 0.014$ \\
\hline & Storm runoff & 5 & $5.46 \pm 1.03$ & $35.12 \pm 2.26$ & $2.01^{\star} \pm 0.139$ & $0.19^{*} \pm 0.022$ & $0.10^{*} \pm 0.022$ & $0.03^{\star} \pm 0.022$ & $0.05 \pm 0.000$ \\
\hline & Groundwater & 32 & - & $23.92 \pm 2.19$ & $0.52^{\star} \pm 0.068$ & $0.06 \pm 0.006$ & $0.11^{\star} \pm 0.016$ & $0.03^{\star} \pm 0.002$ & $0.03 \pm 0.003$ \\
\hline \multirow[t]{4}{*}{2} & Annie Creek & 17 & $42.42 \pm 16.88$ & - & $0.10 \pm 0.025$ & $0.03 \pm 0.001$ & $0.01 \pm 0.002$ & $0.02 \pm 0.002$ & $0.03 \pm 0.001$ \\
\hline & Inflow & 25 & $36.58 \pm 9.08$ & $4.64 \pm 0.154$ & $0.29 \pm 0.074$ & $0.04 \pm 0.003$ & $0.03 \pm 0.000$ & $0.03 \pm 0.001$ & $0.02 \pm 0.002$ \\
\hline & Outflow & 59 & $23.96 \pm 2.14$ & $14.37 \pm 1.107$ & $0.96^{\star} \pm 0.042$ & $0.09 \pm 0.017$ & $0.08 \pm 0.003$ & $0.05 \pm 0.000$ & $0.05 \pm 0.014$ \\
\hline & Groundwater & 15 & - & $32.40 \pm 6.10$ & $1.27^{\star} \pm 0.271$ & $0.07 \pm 0.009$ & $0.10 \pm 0.011$ & $0.04 \pm 0.006$ & $0.02 \pm 0.004$ \\
\hline
\end{tabular}

${ }^{1}$ TOC indicates total organic carbon; TDP, total dissolved phosphorus; ortho-P, orthophosphate as $\mathrm{P}$; TDN, total dissolved nitrogen; $\mathrm{NH}_{4}^{+}-\mathrm{N}$, ammonia- $\mathrm{N}$; $\mathrm{NO}_{3}^{-}-\mathrm{N}$, nitrate- $\mathrm{N}$; and - , constituent was below instrument detection limit. 


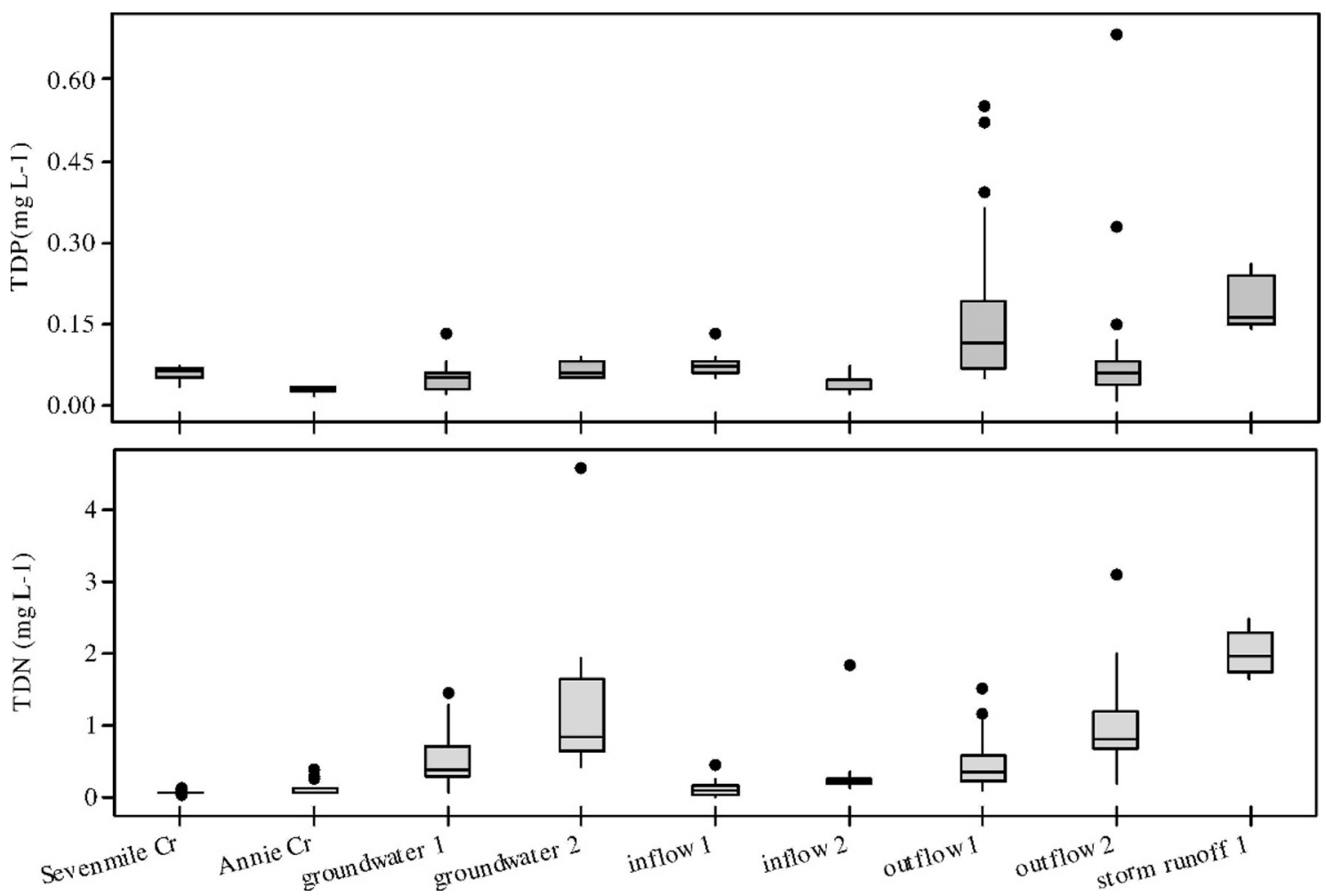

Figure 1. Distribution of total dissolved phosphorus (TDP) and total dissolved nitrogen (TDN) from background (nearby headwater stream), inflow (irrigation water at point of diversion), outflow (irrigation surface runoff), storm runoff (surface water), and groundwater (at about 1-m depth) samples. Distribution is represented as a box (median, 25th, and 75th percentiles) and whisker (values within 1.5 times the difference between the 25th and 75th percentiles) and extreme values (asterisks) plot.
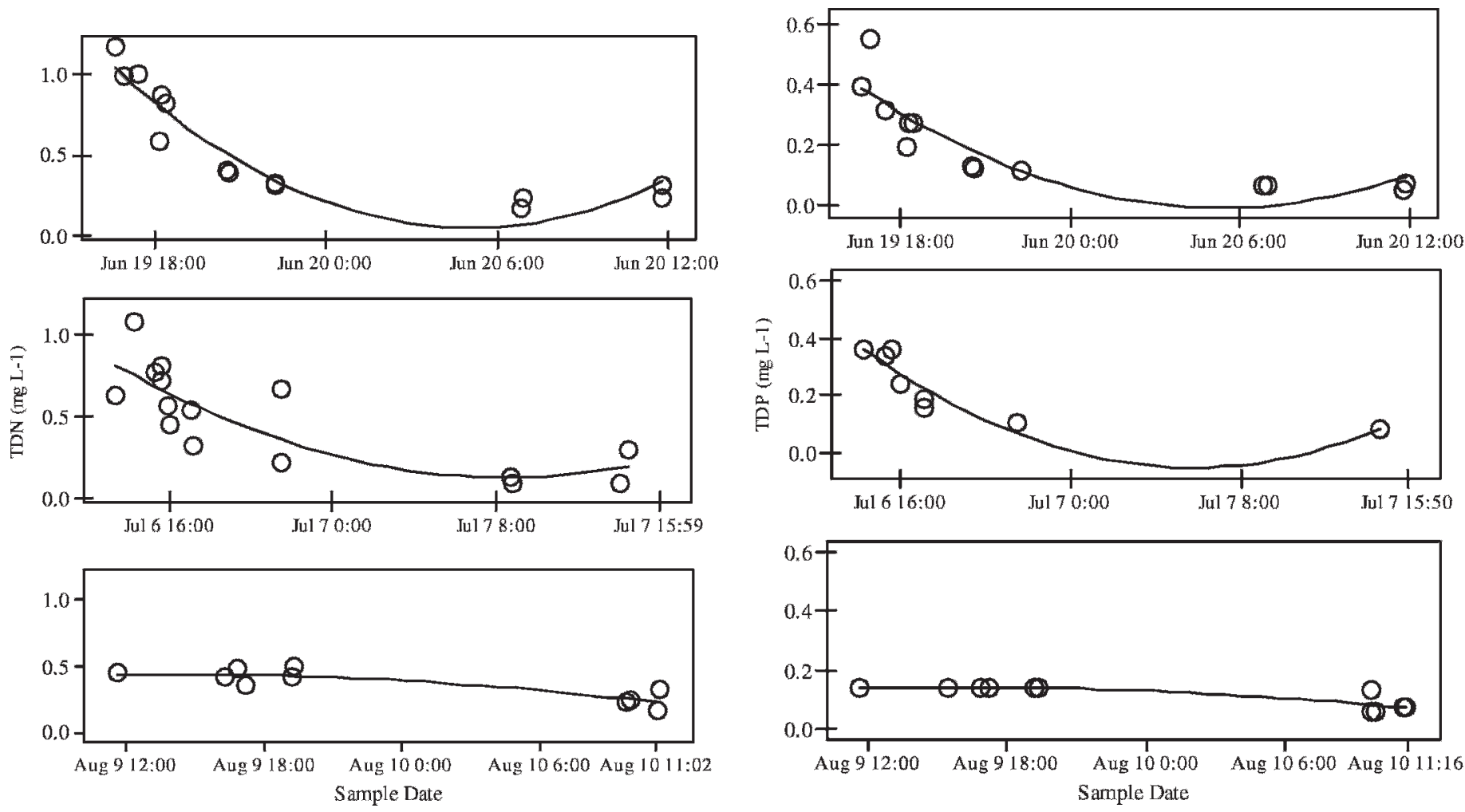

Figure 2. Concentration of total dissolved nitrogen (TDN) in surface water runoff during three irrigation events.

Figure 3. Concentration of total dissolved phosphorus (TDP) in surface water runoff during three irrigation events for a 2-ha pasture (Site 1). 


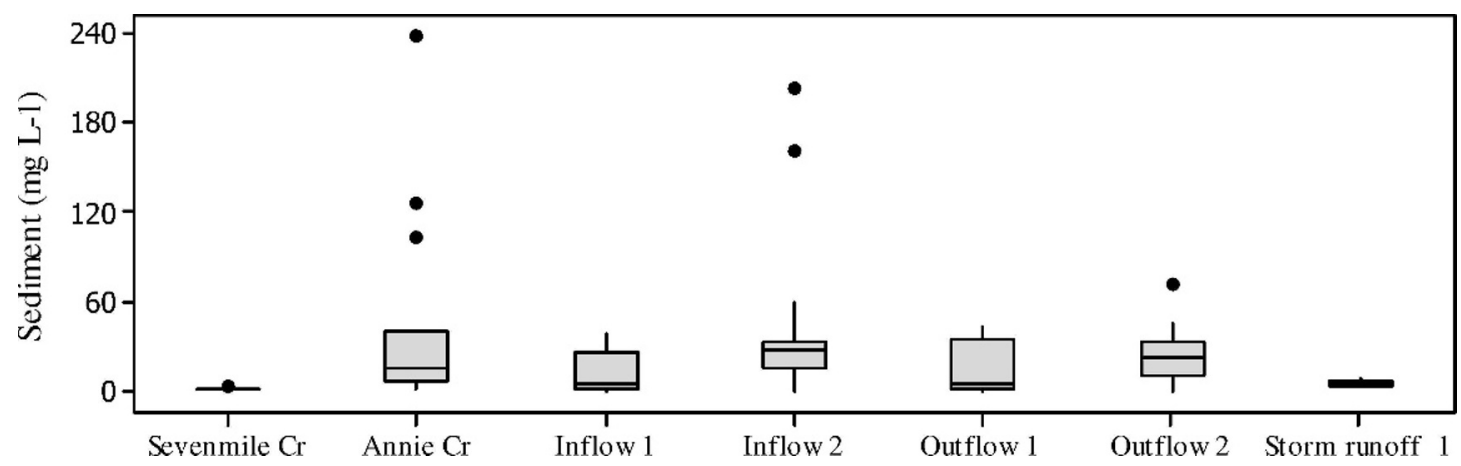

Figure 4. Distribution of sediment concentration from background (nearby headwater stream), inflow (irrigation water at point of diversion), outflow (irrigation surface runoff), and storm runoff (surface water) samples. Distribution is represented as a box (median, 25th, and 75th percentiles) and whisker (values within 1.5 times the difference between the 25th and 75th percentiles) and extreme values (asterisks) plot.

Both sites had soil test $\mathrm{P}$ below $50 \mathrm{mg} \mathrm{P} \cdot \mathrm{kg}^{-1}$ and the soil was more likely a sink for $\mathrm{P}$ than a source.

Sediment concentrations were generally higher at Site 2 (Fig. 4). The maximum sediment concentration measured in this study was $257 \mathrm{mg} \cdot \mathrm{L}^{-1}$ from a headwater stream, Annie Creek, which provides irrigation source water to Site 2. Annie Creek flows out of Crater Lake National Park and has high sediment concentrations due to springtime and early summer snow melt. The raw mean sediment concentration in Site 2 irrigation inflow was higher $\left(36.5 \mathrm{mg} \cdot \mathrm{L}^{-1}\right)$ than in irrigation surface runoff $\left(23.9 \mathrm{mg} \cdot \mathrm{L}^{-1}\right)$. Site $2 \mathrm{had}$ high sediment concentration in irrigation surface runoff only when cattle were present. The lower concentrations in the irrigation surface runoff likely occur because sediment deposits on the lowgradient pastures.

Site 1 irrigation source water is from Sevenmile Creek, which had a maximum sediment concentration of only $3.42 \mathrm{mg} \cdot \mathrm{L}^{-1}$. The creek is fed primarily by springs from the Winema National Forest. The raw mean sediment concentration of irrigation surface runoff $\left(16.5 \mathrm{mg} \cdot \mathrm{L}^{-1}\right)$ from Site 1 was higher than the irrigation inflow raw mean concentration $\left(13.7 \mathrm{mg} \cdot \mathrm{L}^{-1}\right)$ and significantly higher than raw mean irrigation source water sediment concentration $(P<0.05$; ANOVA).

\section{Nutrient and Sediment Export from Irrigated Pasture}

During the 23 July 2003 and 9 August 2003 irrigations, surface flow and surface sediment and dissolved nutrient export were estimated (Table 3). An attempt was made to estimate nutrient export in subsurface flow from the irrigation sites. Cuenca et al. (1992) characterized the Klamath Basin as having a crop water requirement $\left(\mathrm{ET}_{\mathrm{crop}}\right)$ for pasture of $196 \mathrm{~mm}$ and $155 \mathrm{~mm}$ for the months of July and August, respectively. Food and Agricultural Organization Penman-Montieth reference evapotranspiration $\left(\mathrm{ET}_{\mathrm{o}}\right)$ was determined from meteorological data at a weather station about $1000 \mathrm{~m}$ east of the Site 1 . Based on these data an average daily estimated reference ET was determined to be $5.0 \mathrm{~mm} \cdot \mathrm{d}^{-1}$ and $4.5 \mathrm{~mm} \cdot \mathrm{d}^{-1}$ for July and August, respectively. Based on these ET estimates the subsurface runoff volumes were $19 \%$ and $4 \%$ of the headwater irrigation application during the July and August irrigations, respectively. Depth to groundwater was between $0.91 \mathrm{~m}$ and $1.52 \mathrm{~m}$ prior to the July and August irrigations and $<0.31 \mathrm{~m}$ during the irrigation. Lateral seepage to and from neighboring irrigated fields was not quantified. Assumptions were not made about the subsurface flow exchange onto and away from the study site so the subsurface portion of the overall nutrient budget was not estimated.

Table 3. Export and yield of sediment, TOC, ${ }^{1} \mathrm{TDP}$, ortho- $\mathrm{P}, \mathrm{TDN}, \mathrm{NH}_{4}^{+}-\mathrm{N}$, and $\mathrm{NO}_{3}^{-}-\mathrm{N}$ at study Site 1 during two irrigation events. Concentrations of $\mathrm{NO}_{3}^{-}-\mathrm{N}$ and $\mathrm{NH}_{4}^{+}-\mathrm{N}$ were undetected during certain irrigation events.

\begin{tabular}{|c|c|c|c|c|c|c|c|c|c|}
\hline Irrigation date & Site 1 & Flow $\left(\mathrm{m}^{3}\right)$ & Sediment & DOC & TDN & $\mathrm{NH}_{4}^{+}-\mathrm{N}$ & $\mathrm{NO}_{3}^{-}-\mathrm{N}$ & TDP & Ortho-P \\
\hline \multirow[t]{4}{*}{23 July 2003} & Inflow & 8600 & 113.4 & 97.2 & 0.74 & - & - & 0.48 & 0.48 \\
\hline & Outflow & 5740 & 170.1 & 77.9 & 1.19 & - & - & 0.45 & 0.43 \\
\hline & Net outflow & -2860 & 56.7 & -19.3 & 0.46 & - & - & -0.03 & -0.05 \\
\hline & Yield $\left(\mathrm{kg} \cdot \mathrm{ha}^{-1}\right)$ & - & 28.3 & -9.6 & 0.23 & - & - & -0.02 & -0.03 \\
\hline \multirow[t]{4}{*}{9 August 2003} & Inflow & 4355 & 12.7 & 42.1 & 0.45 & 1.09 & - & 0.47 & 0.30 \\
\hline & Outflow & 3093 & 51.9 & 42.4 & 1.03 & 1.39 & - & 0.36 & 0.22 \\
\hline & Net outflow & -1262 & 39.2 & 0.4 & 0.58 & 0.30 & - & -0.11 & -0.08 \\
\hline & Yield $\left(\mathrm{kg} \cdot \mathrm{ha}^{-1}\right)$ & - & 19.6 & 0.2 & 0.29 & 0.15 & - & -0.06 & -0.04 \\
\hline
\end{tabular}

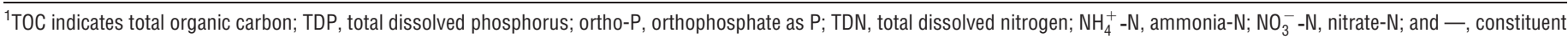
was below instrument detection limit. 
Table 4. Mean flow-weighted concentrations of TOC, ${ }^{1} \mathrm{TDP}$, ortho-P, $\mathrm{TDN}, \mathrm{NH}_{4}^{+}-\mathrm{N}$, and $\mathrm{NO}_{3}^{-}-\mathrm{N}$ at inflow (point of irrigation diversion) and outflow (irrigation surface runoff) locations at study Site 2, a 70-ha cattle pasture.

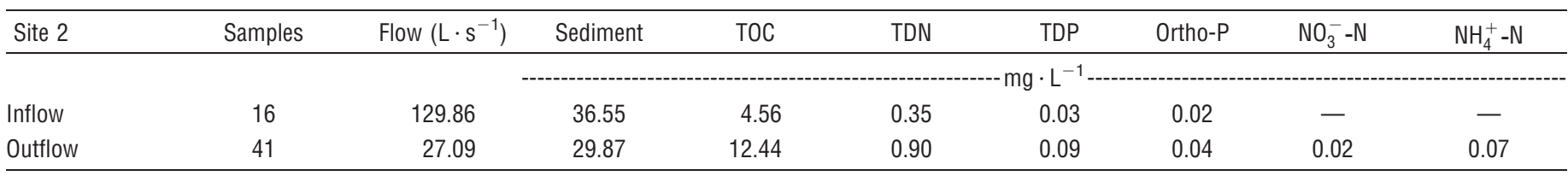

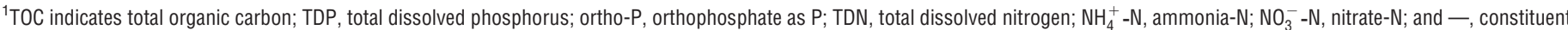
was below instrument detection limit.

The surface irrigation surface runoff was $67 \%$ and $71 \%$ of inflow volume. There was a mean yield of $24 \mathrm{~kg} \cdot \mathrm{ha}^{-1}$ of sediment and $0.26 \mathrm{~kg} \mathrm{~N} \cdot \mathrm{ha}^{-1}$ of TDN per irrigation. Export of $\mathrm{NH}_{4}^{+}-\mathrm{N}$ occurred only during the 9 August irrigation and was undetected in the 23 July irrigation. $\mathrm{NO}_{3}^{-}-\mathrm{N}$ was undetected during both irrigation events. There was a small net retention of TDP and ortho-P. Because this nutrient budget does not include export from subsurface flow or the particulate fraction of the $\mathrm{P}$ or $\mathrm{N}$, it does not provide a complete nutrient budget for the site. The export of sediment during both irrigations indicates that the particulate forms of both $\mathrm{N}$ and $\mathrm{P}$ exported from the site may be considerable. TDN in subsurface samples was high and likely contributed to the overall $\mathrm{N}$ budget whereas TDP concentration in subsurface samples was low and would likely have a minimal contribution.

Site 2 topography did not allow for accurate measurement of all irrigation surface runoff so only FWCs were computed at Site 2. The raw mean FWC for all nutrients were higher in the irrigation surface runoff than in inflow (Table 4). FWC of TDP in irrigation surface runoff was typically around $0.06 \mathrm{mg}$ $\mathrm{P} \cdot \mathrm{L}^{-1}$. The raw mean FWC of sediment in the irrigation inflow at Site 2 was higher than that measured in the surface runoff. On two occasions the sediment FWC in irrigation surface runoff increased from about $12.5 \mathrm{mg} \cdot \mathrm{L}^{-1}$ to $51.3 \mathrm{mg} \cdot \mathrm{L}^{-1}$ at Site 2. Cattle were observed in canals during these occasions.

\section{Water Quality of Storm Runoff}

The only storm to produce surface runoff during the study period occurred on 9 September 2003. Both TDN and TDP in the storm surface runoff were high $\left(2.01 \mathrm{mg} \mathrm{N} \cdot \mathrm{L}^{-1}\right.$ and $0.19 \mathrm{mg} \mathrm{P} \cdot \mathrm{L}^{-1}$, respectively) relative to most other surface samples. Most of the TDP and TDN were organic. The storm surface runoff was sheet flow and did not produce enough flow volume to measure at the Site 1 weir. Sediment concentration in the storm surface runoff at Site 1 was low $\left(5.46 \mathrm{mg} \cdot \mathrm{L}^{-1}\right)$.

\section{DISCUSSION}

Transport of pollutants from Site 1 occurred from excess surface water flow off the pasture during irrigation. The mobilization and transport of dissolved nutrients may occur as surface runoff first flows over the pasture and nutrients diffuse into the surface runoff water (Bondurant 1971; Fraser et al. 1994). Mundy et al. (2003) observed that cattle stocking density influenced $\mathrm{N}$ and $\mathrm{P}$ concentration in irrigation water only for the first irrigation and that subsequent irrigations had similar $\mathrm{N}$ and $\mathrm{P}$ in surface runoff regardless of stock density.
This is likely due to the time needed for accumulation and mineralization of organic matter from soil, vegetation, and livestock waste between irrigations. As the irrigation season continues and surface runoff is frequent there is less easily mobile material for transport (Fitzsimmons et al. 1972). This seems to be particularly true if total pasture coverage is maintained, as was the case for Site 1 in this study. Dissolved nutrient concentrations were lower during the Site 1 August irrigations than they were in June and July. The decrease in dissolved nutrients in irrigation surface runoff may also be attributed to increased biological uptake later in the summer. Site 2 provided easier access to canals and bare soil spots for cattle, resulting in nutrient and sediment pulses in irrigation surface runoff throughout the season.

At Site 1 the irrigation efficiency was low and about $70 \%$ of applied irrigation water was surface runoff. Improved irrigation efficiency would likely reduce sediment and $\mathrm{NH}_{4}^{+}-\mathrm{N}$ export because they were variable throughout the entire surface runoff period. Because a majority of the dissolved $\mathrm{N}$ and $\mathrm{P}$ loss occurs at the beginning of the surface runoff period, a reduction of dissolved $\mathrm{N}$ and $\mathrm{P}$ export would likely be small unless efficiency was improved considerably. Heathwaite et al. (2000) found that strategies for controlling $\mathrm{N}$ and $\mathrm{P}$ surface runoff often differ and may be in conflict where a reduction in $\mathrm{P}$ surface runoff may result in increased nitrate leaching. If surface runoff is reduced during irrigation, then TP loss is reduced (Sharpley and Syers 1976; Thorrold et al. 1999). Sharpley et al. (2000) found that areas controlling a majority of $\mathrm{P}$ transport are from a limited part of the agricultural landscape. At Site 1 the source of dissolved P appears to be from organic matter decomposition from the overall pasture surface.

The results from the 2003 and 2004 subsurface water quality were similar. The TDP concentration in the subsurface was low relative to surface water TDP. Evangelou (1998) found that unlike $\mathrm{N}$, the excretion of $\mathrm{P}$ occurs largely in cattle feces and not in the urine that often leaches into the soil. Dissolved $\mathrm{P}$ concentrations in subsurface runoff may also be low because $\mathrm{P}$ tends to bind with P-deficient soil particles (Sharpley et al. 2001). Sharpley et al. (1996) found that 9\% of P applied to a field was lost in surface runoff and less than $1 \%$ in subsurface runoff.

Inorganic $\mathrm{N}$ made up about $25 \%$ of the TDN concentration in the subsurface water. $\mathrm{NH}_{4}^{+}-\mathrm{N}$ was the primary inorganic $\mathrm{N}$ form; $\mathrm{NO}_{3}^{-}-\mathrm{N}$ was not detected. Increased water supply in high $\mathrm{N}$ content areas such as urine patches can lead to nitrate leaching and $\mathrm{N}$ in urine is often readily available to plants because urea is quickly hydrolyzed into $\mathrm{NH}_{4}^{+}-\mathrm{N}$ and $\mathrm{NO}_{3}^{-}-\mathrm{N}$ 
(Ball et al. 1979). Fraser (1994) studied the fate of ${ }^{15} \mathrm{~N}$-labelled synthetic urine $\left(50 \mathrm{~g} \mathrm{~N} \cdot \mathrm{m}^{-2}\right)$ applied to an irrigated pasture and found that $8 \%$ was leached out. Soils lower in the valley near the edges of major drainage ways may have higher $\mathrm{P}$ accumulation and decreased $\mathrm{P}$ absorption potential (Gillingham and Thorrold 2000). Wetlands at the northern edge of Agency Lake had large export rates of both TN and TP (Snyder and Morace 1997).

Even with improved irrigation efficiency there would be nutrient export from pastures during late summer and fall storm events such as occurred during the 9 September 2003 storm. Jawson et al. (1982) found the bulk $(60-90 \%)$ of the nutrient surface runoff from grazing land occurred during the first precipitation event following the summer grazing period. Storm water nutrient loads from low-gradient $(<5 \%$ slope $)$ and vegetated pastures are most likely dependent on the antecedent soil moisture (Gburek and Sharpley 1998). The storm water surface runoff at Site 1 had high dissolved nutrient concentrations but low sediment concentration and flow volume. Although the storm event was seemingly small at the plot scale it occurred simultaneously throughout the Upper Klamath Lake watershed and many streams and irrigation canals experienced annual maximum nutrient concentrations and loads (Klamath Basin Rangeland Trust 2003). At the end of the irrigation season most of the pastures in the Upper Klamath Lake watershed are prone to rapid storm surface runoff events because they are already saturated and hydrologically connected to canals and natural waterways. The storm event also resulted in high concentrations of sediment from portions of the watershed. Site 2 had more canal access areas and bare soil ground.

Kaufman et al. (2004) found that significant changes in soil, hydrologic, and vegetation properties resulted following removal of livestock along the Middle Fork John Day River in Oregon. Maintaining healthy wetlands and vegetated buffers between pastures and waterways was demonstrated to reduce sediment and $\mathrm{NO}_{3}^{-}-\mathrm{N}$ transport to waterways (Gilliam 1994; Griffith et al. 1997). P retention in vegetative buffers also occurs (Chescheir et al. 1991; Gilliam 1994). When considering such management options for reducing environmental impacts of sediment and nutrients, it is important to first focus on areas that can transport pollutants directly to sensitive waterways, such as canals emptying directly into streams (Sharpley et al. 2000).

The quality of irrigation source water also played an important role in overall irrigation runoff water quality. Site 1 had high dissolved $\mathrm{P}$ concentration $\left(0.05 \mathrm{mg} \mathrm{P} \cdot \mathrm{L}^{-1}\right)$ in irrigation source water relative to Site 2, whereas Site 2 had high irrigation source water sediment concentration $\left(42.4 \mathrm{mg} \cdot \mathrm{L}^{-1}\right)$ and the highest recorded sediment concentration during a late summer storm event. Recognizing local variability in irrigation source water nutrient and sediment concentrations can assist in identifying specific farm management practices to improve water quality.

\section{IMPLICATIONS}

In this study, the irrigation source water nutrient and sediment concentrations were variable within the same watershed. Concentrations and FWCs for all nutrients were generally higher in irrigation surface runoff than in applied irrigation water or irrigation source waters (naturally flowing stream). Reducing the transport of nutrients from irrigated pastures would require a considerable reduction in irrigation surface runoff. In this study, the 2-ha location (Site 1) had few bare soil spots and provided no access areas for cattle to drainage canals. These management practices and the relatively low cattle stocking density may in part be responsible for the TDP retention observed during two irrigations. Because the particulate $\mathrm{P}$ fraction was not measured it could not be determined if Site 1 was a net sink for P.

The 70-ha location (Site 2) had consistently higher FWCs of nutrients in irrigation surface runoff than in applied irrigation water. At Site 2 there were barren soil areas along irrigation canals and cattle were observed in flowing irrigation canals. Sediment concentrations in irrigation source water were also high at Site 2 due to spring runoff from Crater Lake National Park. In this semiarid climate, nutrient export will likely continue to occur from grazed pasture during late summer and early fall storm events.

\section{LITERATURE CITED}

AndeRson, J. K. 1998. A management model for determining optimal watershed management strategies for reducing lake total phosphorous concentrations: application to Upper Klamath Lake, Oregon [thesis]. Arcata, CA, USA: Humboldt State University.

Ball, R., D. R. Keeney, P. W. Theobald, and P. Nes. 1979. Nitrogen balance in urine affected areas of a New Zealand pasture. Agronomy Journal 71:309-314.

BonduRANT, J. A. 1971. Quality of surface irrigation surface runoff water. Transactions of the American Society of Agricultural and Biological Engineers 14:1001-1003.

Bush, B., AND N. Austin. 2001. Timing of phosphorus fertilizer application within an irrigation cycle for perennial pasture. Journal of Environmental Quality 30:939-946.

Cessna, A. J., J. A. Elliott, L. Tollefson, and W. Nicholaichuk. 2001. Herbicide and nutrient transport from an irrigation district into the South Saskatchewan River. Journal of Environmental Quality 30:1796-1807.

Chescheir, G. M., J. W. Gilliam, R. W. Skaggs, and R. G. Broadhead. 1991. Nutrient and sediment removal in forested wetlands receiving pumped agricultural drainage water. Wetlands 11:87-103.

Cuenca, R. H., J. L. Nuss, A. Martinez, G. Katul, and J. González. 1992. Oregon crop water use and irrigation requirements. Corvallis, OR, USA: Oregon State University Extension Service, Extension Miscellaneous 8530. 564 p.

Evangelou, V. P. 1998. Environmental soil and water chemistry: principles and application. New York, NY, USA: John Wiley and Sons. 252 p.

Fitzsimmons, D. W., G. C. Lewis, D. V. Naylor, and J. R. Busch. 1972. Nitrogen, phosphorus and other inorganic materials in a gravity-irrigated area. Transactions of the American Society of Agricultural and Biological Engineers 15:292-295.

Fraser, P. P., K. C. Cameron, and R. R. Sherlock. 1994. Lysimeter study of the fate of nitrogen in animal urine returns to irrigated pasture. European Journal of Soil Science 45:439-447.

Gburek, J. W., and A. N. Sharpley. 1998. Hydrologic controls on phosphorus loss from upland agricultural watersheds. Journal of Environmental Quality 27:267-277.

Gearheart, R. A., J. K. Anderson, M. G. Forbes, M. Osburn, and D. Oros. 1995. Watershed strategies for improving water quality in Upper Klamath Lake, Oregon. Volumes I, II, and III. Arcata, CA, USA: Humboldt State University. $270 \mathrm{p}$.

GILLIAM, J. W. 1994. Riparian wetlands and water quality. Journal of Environmental Quality 23:896-900. 
Gillingham, A. G., and B. S. Thorrold. 2000. A review of New Zealand research measuring phosphorus in runoff from pasture. Journal of Environmental Quality 29:88-96.

Griffith, S. M., J. S. Owen, W. R. Howrath, P. J. Wigington, JR., J. E. Baham, and L. F. ElLIOTT. 1997. Nitrogen movement and water quality at a poorly drained agricultural and riparian site in the Pacific Northwest. Soil Science and Plant Nutrition 43:1025-1030.

Heathwaite, A. L., A. N. Sharpley, and W. J. Gburek. 2000. A conceptual approach for integrating phosphorus and nitrogen management at the watershed scales. Journal of Environmental Quality 29:158-166.

Jawson, M. D., L. F. Elliott, K. E. Saxton, and D. H. Fortier. 1982. The effect of cattle grazing on nutrient losses in a Pacific Northwest setting. Journal of Environmental Quality 11:628-631.

Kaufman, J. B., A. S. Thorpe, and E. N. J. Brookshire. 2004. Livestock exclusion and belowground ecosystem responses in riparian meadows of eastern Oregon. Ecological Applications 14:1671-1679.

Klamath Basin Rangeland Trust. 2003. Pilot project monitoring report. Volume 2: water quality baseline survey. Ashland, OR, USA: Klamath Basin Rangeland Trust. $42 \mathrm{p}$.

Lewis, D. J., M. J. Singer, R. A. Dahlgren, and K. W. Tate. 2006. Nitrate and sediment fluxes from a California rangeland watershed. Journal of Environmental Quality 35:2202-2211.

Maidment, D. R. 1993. Handbook of hydrology. New York, NY, USA: McGraw-Hill. $1424 \mathrm{p}$.

Mundy, G. H., K. J. Nexhip, N. R. Austin, And M. D. Coluins. 2003. The influence of cutting and grazing on phosphorus and nitrogen in irrigation surface runoff from a perennial pasture. Australian Journal of Soul Research 41:675-685.

Nelson, P. N., E. Cotsaris, and M. J. Oades. 1996. Nitrogen, phosphorus, and organic carbon in streams draining two grazed catchments. Journal of Environmental Quality 25:1221-1229.

Oregon Department of Environmental Quality. 2002. Upper Klamath Lake drainage total maximum daily load (TMDL) and water quality management plan (WQMP). Portland, OR, USA: Oregon Department of Environmental Quality. $188 \mathrm{p}$.

Owens, L. B., W. M. Edwards, and R. Van Keuren. 1989. Sediment and nutrient losses from an unimproved, all-year grazed watershed. Journal of Environmental Quality 18:232-238.

RykBOSt, K. A., AND B. A. CharLton. 2001. Nutrient loading of surface waters in the Upper Klamath Basin: agricultural and natural sources. Corvallis, OR, USA: Oregon State University Agricultural Experiment Station, Special Report 1023. 14 p.

Schepers, J. S., AND D. D. Francis. 1982. Chemical water quality of surface runoff from grazing land in Nebraska: I. Influence of grazing livestock. Journal of Environmental Quality 11:351-354.
Sether, B. A., W. R. Berkas, and A. V. Vecchia. 2004. Constituent loads and flowweighted average concentrations for major subbasins of the Upper Red River of the North Basin, 1997-99. Reston, VA, USA: US Geological Survey, Scientific Investigations Report 2004-520. 62 p.

Sharpley, A. N., T. C. Daniel, J. T. Simms, and D. H. Pote. 1996. Determining environmentally sound soil phosphorus levels. Journal of Soil Water Conservation 51:437-451.

Sharpley, A. N., B. Foy, and P. Withers. 2000. Practical and innovative measures for the control of agricultural phosphorus losses to water: an overview. Journal of Environmental Quality 29:1-9.

Sharpley, A. N., R. W. McDowell, and P. J. A. Kleinman. 2001. Phosphorus loss from land to water: integrating agricultural and environmental management. Plant and Soil 237:287-307.

Sharpley, A. N., AND J. K. Syers. 1979. Loss of nitrogen and phosphorus in tile drainage as influenced by urea application and grazing animals. New Zealand Journal of Agricultural Research 22:127-131.

Snyder, D. T., and J. L. Morace. 1997. Nitrogen and phosphorus loading from drained wetlands adjacent to Upper Klamath and Agency Lakes, Oregon. Portland, OR, USA: US Geological Survey, Water-Resources Investigations Report 97-4059. $67 \mathrm{p}$.

Thorrold, B. S., R. Wilcock, R. Monaghan, M. Stroud, and K. Hamil. 1999. Catchment scale effects of land use and management on $\mathrm{N}$ and $\mathrm{P}$ losses in surface runoff water. In: L. D. Currie and P. Longananthan [EDS.]. Long term nutrient needs of New Zealand's primary industries: global supply, production requirements and environmental constraints. Palmerston North, New Zealand: Fertiliser and Lime Research Centre, Massey University. p. 55-66.

[USDA nRCS] US Department of Agriculture Natural Resources Conservation Service. 1985. Soil survey of Klamath County, Oregon: southern part. Available at: http://soildatamart.nrcs.usda.gov/Manuscripts/0R640/0/0r640_text.pdf. Accessed 5 December 2009.

[USDA nRCS] US Department of Agriculture Natural Resources Conservation Service. 1997. Broad land cover/use, by state 1997. Available at: http://www. nrcs.usda.gov/technical/NRI/maps/cover_use.html. Accessed 5 December 2009.

[USDA nRCS] US Department of Agriculture Natural Resources Conservation Service. 2005. Upper Klamath Lake - 18010203: 8-digit hydrologic unit profile. Available at: ftp://ftp-fc.sc.egov.usda.gov/OR/HUC/basins/highdesert/18010203_ 09-13-05.pdf. Accessed 5 December 2009.

uS Department of the Interior Bureau of Reclamation. 1997. Water measurement manual. 3rd ed. Washington, DC, USA: US Department of the Interior Bureau of Reclamation. $485 \mathrm{p}$. 